\title{
Meeting Corporate Renewable Power Targets
}

Trivella, Alessio; Mohseni-Taheri, Danial; Nadarajah, Selvaprabu

Publication date:

2018

Document Version

Peer reviewed version

Link back to DTU Orbit

Citation (APA):

Trivella, A., Mohseni-Taheri, D., \& Nadarajah, S. (2018). Meeting Corporate Renewable Power Targets. Abstract from 29th European Conference On Operational Research, Valencia, Spain.

\section{General rights}

Copyright and moral rights for the publications made accessible in the public portal are retained by the authors and/or other copyright owners and it is a condition of accessing publications that users recognise and abide by the legal requirements associated with these rights.

- Users may download and print one copy of any publication from the public portal for the purpose of private study or research.

- You may not further distribute the material or use it for any profit-making activity or commercial gain

- You may freely distribute the URL identifying the publication in the public portal

If you believe that this document breaches copyright please contact us providing details, and we will remove access to the work immediately and investigate your claim 
EURO 2018

29th European Conference on Operational Research

July 8-11, Valencia, Spain

\title{
Meeting Corporate Renewable Power Targets
}

\author{
Alessio Trivella [SPEAKER] \\ Department of Management Engineering, Technical University of Denmark \\ atri@dtu.dk \\ Danial Mohseni-Taheri, Selvaprabu Nadarajah \\ College of Business Administration, University of Illinois at Chicago \\ \{smohse3@uic.edu, selvan@uic.edu\}
}

ABSTRACT: Large companies have recently started to incorporate renewable energy standards in their corporate sustainability goals. In particular, several companies have committed to procure a specific percentage of their electricity demand from renewable sources, i.e., reach a renewable power target by a future date. Dominant corporate procurement strategies include (i) buying power from the spot market and supplementing it with renewable energy certificates (RECs) and (ii) entering long-term bilateral contracts known as power purchase agreements (PPAs) to buy power directly from a renewable generator. Constructing a multi-period procurement portfolio containing these buying options is complex due to stochastic power demand as well as volatile power and RECs prices. In this work, we study how to set up a power sourcing policy to reach a renewable target and sustain it at minimum expected cost. We provide analytical insights on stylized models containing a few periods. We also formulate a multi-period Markov decision process (MDP) that incorporates a PPA pricing model consistent with practice. This MDP has high-dimensional endogenous and exogenous components in its state and is thus intractable. We overcome this intractability by developing a heuristic policy based on a new dual reoptimization scheme that relies on information relaxations. We find that our dual reoptimization approach outperforms commonly used primal reoptimization methods and simple heuristics on realistic instances. 